
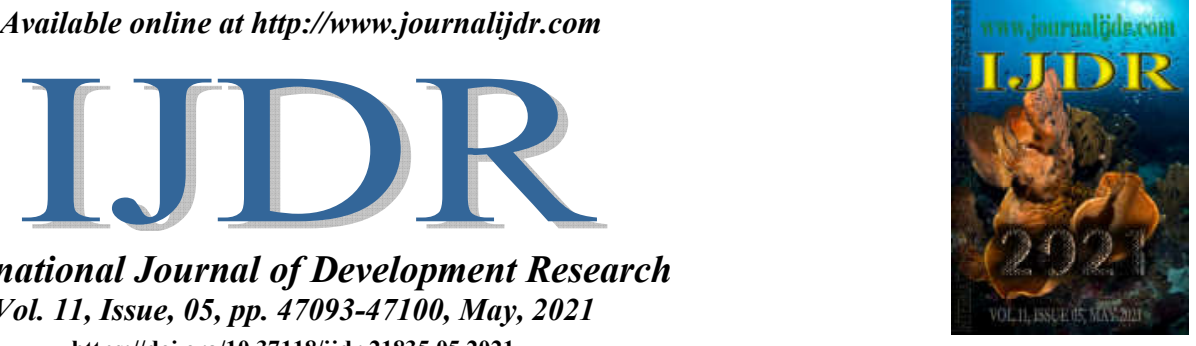

ISSN: 2230-9926

International Journal of Development Research

Vol. 11, Issue, 05, pp. 47093-47100, May, 2021

https://doi.org/10.37118/ijdr.21835.05.2021

\title{
FAMILY AGRICULTURE AS A MEANS FOR SUSTAINABLE LOCAL DEVELOPMENT IN BRAZIL
}

\section{*1Ted Dal Coleto, ${ }^{2}$ Cândido Ferreira da Silva Filho, ${ }^{2}$ Samuel Carvalho De Benedicto and ${ }^{2}$ Vinícius Eduardo Ferrari}

\begin{abstract}
1Pontifícia Universidade Católica de Campinas, Centro de Economia e Administração, Mestrando em Sustentabilidade Rua Professor Doutor Euryclides de Jesus Zerbini, 1516, 13087-571 - Campinas - SP - Brazil

2Pontifícia Universidade Católica de Campinas, Centro de Economia e Administração, Programa de Pós-Graduação Stricto Sensu em Sustentabilidade, Rua Professor Doutor Euryclides de Jesus Zerbini, 1516, 13087-571 - Campinas - SP - Brazil
\end{abstract}

\section{ARTICLE INFO}

\section{Article History:}

Received $09^{\text {th }}$ February, 2021

Received in revised form

$17^{\text {th }}$ March, 2021

Accepted $24^{\text {th }}$ April, 2021

Published online $30^{\text {th }}$ May, 2021

Key Words:

Sustainable development, Local development, Family farming, Organic products,

Agribusiness production.

*Corresponding autho:

Ted Dal Coleto.

\begin{abstract}
The objective of the article is to discuss the opportunity of family farming as a means to ensure sustainable local development in Brazil. In methodological terms, the research can be classified as qualitative and descriptive. For data collection, the research can be classified as bibliographic and documentary. The results indicate that family farming is an important source of job and income generation, contributes to gender equality and preservation of woods and forests. Therefore, it contributes to sustainable local development, considering employed people, the number of establishments, the management of the property, which is shared by the family and the presence of women is an incentive for the family to remain in agricultural activity. We also see that there are possibilities for family farming to expand its contribution to the sustainable local development of agribusiness production and organic agriculture. Finally, family farming represents a viable opportunity for sustainable local development.
\end{abstract}

Copyright (C) 2021, Ted Dal Coleto et al. This is an open access article distributed under the Creative Commons Attribution License, which permits unrestricted use, distribution, and reproduction in any medium, provided the original work is properly cited.

Citation: Ted Dal Coleto, Cândido Ferreira da Silva Filho, Samuel Carvalho De Benedicto and Vinícius Eduardo Ferrari, 2021. "Family agriculture as a means for sustainable local development in Brazil", International Journal of Development Research, 11, (05), 47093-47100.

\section{INTRODUCTION}

Development combined with the preservation of the environment is a recurring theme in the academic debate. Thinkers like Solow (1974) understand that there is no incompatibility between economic growth and the environment, because the scientific-technological progress will always be able to introduce the necessary changes that replace the eventual lack of any of the production' $s$ factors. On the other hand, Romeiro (2012) states that it is important to grow while preserving the planet's resources for future generations. Regarding sustainable development Romeiro $(2012$, p. 65) recalls that "to be sustainable, development must be economically sustained (or efficient), socially desirable (or inclusive) and ecologically prudent (or balanced)". However, development cannot be confused with economic growth (Georgescu-Roegen, 2012). In fact, development must be understood as a broad process that serves to expand human capacities, understood as the set of things that people can be, or do, in life (Nações Unidas, nd). On the other hand, local sustainable development concerns human action with the purpose of facing basic problems and reaching the quality of life levels desired by a community.
It involves initiatives shared by the whole community and founded on popular participation, innovation, and entrepreneurship (Kronenberger, 2011). In this sense, family farming has become a fundamental part of local sustainable development due to its relevance in generating jobs and income, providing better living conditions and decent work for the families involved, and preserving the environment (Santos et al., 2014).

Given the above, an important research question arises: does family farming present itself as a viable opportunity for local sustainable development?

The objective of this article is to discuss the opportunity of family farming for local sustainable development and, specifically, its role in the preservation of woods and forests, gender equality, access to land, employed people, production of organic and agribusiness products, and consolidation and growth difficulties, for example, credit access. In Brazil, family farming accounted, in 2017 , for $33 \%$ of the total value of production in rural areas. In the world, $70 \%$ of the food that reaches the consumer comes from small producers. The sector carries an important pillar of world agriculture and, therefore, in 2014, the United Nations set as a main theme for debates the role of small farmers in sustainable rural development. In order to expand 
discussions on the importance of family farming in promoting sustainable development, the FAO office for Latin America and the Caribbean adopted Regional Initiative number 2, named: Family Farming and Inclusive Food Systems for Sustainable Rural Development. One of the main objectives of this initiative is to contribute to the eradication of hunger and poverty and to promote sustainable development by 2025 in Latin America and the Caribbean (FAO, 2017).

\section{THEORETICAL FOUNDATION}

United Nations and Sustainable Development: Sustainable development awareness is increasing in the world, and the discussions emphasize strategies capable of reconciling economic, social, and environmental development. Among the pioneering discussions, we can highlight the Club of Rome that produced the report "The Limits to Growth" (Meadows et al., 1972). TheUnited Nations Conference on the Human Environment, in Stockholm (Sweden), in 1972, which through its Environmental Manifests established the bases for the environmental agenda of the United Nations System (Nações Unidas, nd). In 1987, the Brundtland Commission published a report called "Our Common Future", which established the concept of sustainable development: "Sustainable development that meets the needs of the present without compromising the ability of future generations to meet their own needs" (WCED, 1987, p. 43). Another major world event on development and the environment took place in 1992 in the city of Rio de Janeiro called Rio 92 or "Earth's Summit" and addressed the imperative need for sustainable development, resulting in the "Agenda 21", with the purpose of moving the world away from the unsustainable growth model (Nações Unidas, nd). The UN organized another major event in 2002 in the city of Johannesburg entitled Rio +10 or World Summit on Sustainable Development and had as its main discussion the transformation of Agenda 21 into coordinated goals and actions. In this event, for the first time, issues such as hunger, poverty and human rights were discussed (Diniz, 2011; United Nations, 2002). The events continued with Rio +20 in the city of Rio de Janeiro where the focus was on the green economy and financing strategies for sustainable development (Guimarães; Fontoura, 2012). The most recent event dealing with development took place in New York where the Sustainable Development Goals (SDGs) were established and the 2030 Agenda was proposed with 17 SDGs and 169 goals which, for Veiga (2015), are exhortations, that is, positive wishes. Because goals require precision, dates and statistics. The purpose of Agenda 2030 is to put the world on a sustainable path, eradicating poverty, promoting equality, and saving future generations from the perverse effects of climate change. Thus, the need, on the one hand, for "bold and transformative" measures and, on the other, for the commitment of people, companies, and governments, with the goals to be met by 2030 (United Nations, 2015). The Sustainable Development Goals (SDGs) represent the central axis of the 2030 Agenda, guiding actions in the three dimensions of sustainable development - economic, social, and environmental. The goals of this Agenda are monitored and revised based on a set of indicators developed by the Inter-Agency Group of Experts on the SDG Indicators (SDG Indicators - IAEG-SDG) of the United Nations (UN) and point out the paths to be followed and the measures to be adopted for a more sustainable world (IPEA, 2018).

Dimensions of Sustainable Development: Sen (2010) associated the idea of development with individual freedoms. Development presupposes substantive freedoms, including the ability to avoid hunger, premature mortality, education, and the possibility to actively participate in political life in society (Kang, 2011). In fact, people need to have their civil and political rights secured so that they can have freedom of choice in order to achieve a full life. The expression sustainable development can be understood as "[...] one that meets the needs of the present without compromising the ability of future generations to meet their own needs" (WCED, 1987, p. 19). In this sense, Sachs (2008), states that sustainability has eight dimensions (social, cultural, ecological, environmental, territorial, economic, national and, international policy). Therefore, as proposed by Van
Bellen and Petrassi (2016), the idea of sustainable development admits a plural, interdisciplinary approach and is characterized by the interaction between theoretical, practical, and political elements. Therefore, the relevance of the territorial dimension in discussions about sustainable development, due to its characteristic of reducing inter-regional disparities and environmentally safe development strategies for ecologically fragile areas, highlighting the importance of the place for sustainable development.

Sustainable Local Development: The crisis that started in the 1970s produced a series of changes in the worldwide dominant social structure that shifted the locus of development from the central to the local scope (KOHLRAUSCH, 2019). According to Martins (2002, p. 54) local development is linked to the territorial scale "which allows for the effectiveness of actions and a better monitoring of results". In fact, the interest in local development arises from the inadequacy of Keynesian Fordism to keep the accumulation rates necessary to maintain economic growth (DoCampo, 2007, p. 4). Historically, development strategies from states were either non-existent, as proposed by liberal orthodoxy, or were conducted by the central government through major structuring projects, such as development strategies. However, the economic transformations in the role of the State and the new productive dynamics, demanded a new look at the place as a locus of development. As mentioned by Arenti (2008, p. 22) "[...] the competitiveness policy must take into account the regional comparative advantages, the formation of local clusters and local innovation systems. Given the search for competitiveness through innovation and differentiation, regional and local specificities must be considered." The assumption is that the more decentralized spheres of power have greater knowledge and greater operational capacity to implement development policies. Therefore, the place gains relevance in the development strategy, requiring the participation of the people who are there because they have knowledge and are culturally and socially belonging to the region where they live, enabling local development to take place in an endogenous way (Albagli, 2006). The emergence of sustainable local development allows for the rise of more sustainable communities, focused on the development of their specific potential, fostering external exchange due to their local competitive advantages. The locations have different economic, social, cultural, political, and institutional characteristics and, therefore, their capacity for learning and innovation are different (Albagli, 2006). Local development is endogenous and therefore it has control over local transformation and thereby can create competitive advantages with changes in characteristics and attributes generating economic value and also promoting new development standards based on sustainability, being it economic, environmental, and socio-political (Albagli, 2006). From that point on, family farming becomes an important part of the strategy for sustainable local development. When dealing with the possibilities of development, Sachs (2010, p. 25) highlights the good prospects for inclusive rural development and in harmony with the environment in tropical countries, as long as family farming is favored over large heavily mechanized agriculture.

Family Farming: FAO (2017) defines family farming as all familybased agricultural activities and also as a way of classifying agricultural, forestry, fishing, pastoral, and aquaculture production that is managed and operated by a family and that depends mainly on family labor, including both women and men. According to Riedner et al. (2018), family farming is a form of production that allows interaction between management and work, in which farmers themselves command the production process, working with the diversification of cultures and using family work. Family agriculture units are capable of generating and absorbing a significant amount of labor and, consequently, promoting income for many Brazilian families. Through the diversification of crops, small rural properties adopt ecologically more balanced production practices, using industrial inputs on a smaller scale, whose acquisition and use become economically unfeasible for these properties. When dealing with the history of Brazilian family farming, Navarro (2016) states that in view of the implementation of the National Rural Credit System in 1965, there was an intense modernization and strong 
expansion of Brazilian agriculture, from 1968 to 1981. The 1980s and 1990 s, were problematic, but despite this, there was a strong expansion of agricultural production, on technological and productivism bases. The 1990s, in turn, marked a new agricultural and agrarian pattern characterized by the financialization of production. Navarro (2016, p. 36) notes that "there is a trend of privatization of financing among large establishments [...] maintaining official credit as the main credit for small producers". Finally, the financialization of agricultural production mainly affects large rural properties and crops for export. Consequently, the structural heterogeneity of Brazilian agriculture was deepened. In this context, family farming gains relevance as an instrument that promotes local development. If large farms make use of modern labor-saving technologies, family farming is characterized by the intensive use of labor, including members of the same family, and there may be the hiring of temporary wage workers during harvest time (Schneider, 2003). In the case of Brazil, the National Supply Company (CONAB) has the mission of institutionally strengthening and supporting family farming. Among its actions, we highlight the programs for the acquisition of food, the guarantee of minimum prices for family farming, and the support for projects to strengthen family farming (CONAB, nd).

In addition, family farming gained official protection under Law No. $11,326 / 06$, which in its $3^{\text {rd }}$ article establishes:

[...] For the purposes of this Law, family farmers and rural family entrepreneurs are those who practice activities in the rural environment, simultaneously meeting the following requirements: I - do not hold any title, area greater than 4 (four) fiscal modules; II - pre-dominantly use the family's own labor in the economic activities of its establishment or enterprise; III has a family income predominantly originating from economic activities linked to the establishment or enterprise itself; IV - run your establishment or enterprise with your family (Brasil, 2006).

Decree 9.064/17, which regulates the Family Agriculture Law, establishes in Article 2 that the tax module is calculated by the National Institute of Colonization and Agrarian Reform (Incra) and may vary according to the municipality (Brasil, 2017). Also benefiting from the Law are foresters, aquaculturists, extractivists, fishermen, and indigenous and quilombola peoples. Decree No. 9,064/17 regulated Law No. 11,326/06 and established the foundations of the National Family Agriculture Policy (PRONAF).

Bruno (2016, p. 142) highlights that:

[...] the small family farmer who owns land producing for the domestic market has almost always been present on the agenda of the economic and political priorities of rural agribusiness elites in the country. Although at no time he was seen as on an equal footing with large landowners and agribusiness entrepreneurs.

Regarding the competitiveness of agriculture, Batalha, Buainain and Souza Filho $(2005$, p. 2) affirm that the difficulties cannot be explained, for example, by the lack of technology, on the contrary, the performance depends on a set of factors, being a great challenge the development of "a set of mechanisms, public and private, that assist in the operationalization of the coordination of the agribusiness chain and that allow the inclusion of family farming in these systems". In this context that family farming needs support policies to, among other things, be an instrument that promotes sustainable local development. Buainain (2006) mentions that the development of family farming cannot be directed towards itself, and can contribute, among other things, to the generation of wealth, the distribution of income, the strengthening of democracy and the preservation of the environment.

\section{METHODOLOGY}

As for the nature of the problem, the study used a qualitative approach. According to Gil (2019), qualitative research seeks a systematic explanation of facts that occur in the social context, and this is usually related to many of variables. Chizzotti (2018, p. 89) adds that the main purpose of qualitative research "is to intervene in an unsatisfactory situation, to change conditions perceived as transformable", which is consistent with the scope of this work. As for the objectives, this research consists of an exploratory and descriptive study. Exploratory research is characterized by the existence of few available data, in which it is sought to deepen and refine ideas and build hypotheses (Vergara, 2013). For Triviños (2015), this model aims to increase the experience in relation to a certain problem that is still little studied or known. Descriptive research seeks to observe the facts, registering them, classifying, and interpreting them, with no interference from the researcher (Gil, 2019). The descriptive character is based on the intention of the research to describe situations and provide contextual information that may serve as a basis for further explanatory research (Deslauriers; Kérisit, 2010). The research is also characterized as descriptive. According to Severino (2016, p. 123), descriptive research is one that in addition to "registering and analyzing the studied phenomena, seeks to identify their causes." In this sense, we intend to identify the possibilities of contribution of family farming to sustainable local development. Regarding technical procedures, the research is a documentary type. Gil (2019, p. 52) says that documentary research is one that "makes use of materials that have not yet received an analytical treatment, or that can still be reworked according to the objectives of the research". This research is documentary, since the collection of data on family farming and, specifically, organic production, was carried out based on public information available on the websites of research institutes.

As for sampling, this research is an intentional non-probabilistic type (also called rational selection), as elements of the sample that are related are sought, according to the pre-established characteristics (Richardson, 2017), that is, data related to agriculture seeking to provide an answer to the research question: does family farming present itself as a viable opportunity for sustainable local development?

The strategy used for the analysis of the data was the Explanation Building (or construction of the explanation). Through this strategy, we tried to explain not the whole phenomenon, but only some aspects of it. Yin (2015) states that the construction of explanation is one of the dominant analytical techniques in the analysis of study evidences of different natures. The construction of explanation in exploratory studies, according to Yin (2015), should be considered a process that generates hypotheses. The elaboration of the explanation is usually done in a narrative way and must be based on significant theoretical propositions, making it possible to confront the theoretical elements with the research findings.

\section{RESULTS}

Establishments and Land Use: According to the 2017 Census of Agriculture (IBGE, s.d) about 3.9 million agricultural establishments in Brazil are classified as family farming. The area occupied by family farming corresponds to 80.9 million hectares, or $23 \%$ of the area of all agricultural establishments in the country, as shown in table 1 . The value of family agriculture production was $\mathrm{R} \$ 107$ billion in 2017, equivalent to $23 \%$ of all Brazilian agricultural production. The 2017 Agricultural Census (IBGE, 2017) reveals that the states of Pernambuco, Ceará and Acre have the largest proportions of area occupied by family farming. The states of the Midwest and São Paulo have the smallest.

Table 1. Agricultural establishments in Brazil, in 2017

\begin{tabular}{llll}
\hline & $\begin{array}{l}\text { Agricultural } \\
\text { establishments }\end{array}$ & $\begin{array}{l}\text { Non-family } \\
\text { farming }\end{array}$ & Family farming \\
\hline Quantity & 5.073 .324 & 1.175 .916 & 3.897 .408 \\
Area (ha) & 351.298 .816 & 270.398 .732 & 80.891 .084 \\
\hline
\end{tabular}


Regarding the use of land by all establishments, we find that family farming contributes to the sustainability and preservation of the planet as it allocates more than 13.3 million hectares or the equivalent to $16.5 \%$ of the area of family farming establishments, for the preservation of woods and forests. Considering that the family farming is made up of small farms, many of them with production for the subsistence of the rural producer, then, the preservationist effort cannot be neglected (Table 2). Undeniably, family farming contributes to the preservation of the environment. Since it is in the public interest to expand the areas intended to the preservation of woods and forests, policies of income transfer to small rural producers can stimulate the maintenance and, even, the expansion of the preserved areas.

Table 2. Land use by agricultural establishments in Brazil, in hectares, in 2017

\begin{tabular}{llll}
\hline & Area (ha) & $\begin{array}{l}\text { Crops, pastures, } \\
\text { and others (ha) }\end{array}$ & $\begin{array}{l}\text { Preservation } \\
\text { of woods and } \\
\text { forests (ha) }\end{array}$ \\
\hline $\begin{array}{l}\text { Non-family farming } \\
\text { Family farming }\end{array}$ & $\begin{array}{l}270.398 .732 \\
80.891 .084\end{array}$ & $\begin{array}{l}208.778 .772 \\
67.549 .214\end{array}$ & $\begin{array}{l}61.619 .960 \\
13.341 .870\end{array}$ \\
\hline
\end{tabular}

Source: IBGE (2017). Elaborated by the authors.

Employed People and Gender: Of all the people employed in agriculture and livestock, equivalent to 15.1 million, there are $67 \%$ or the equivalent of 10.1 million people, linked to family farming. And among these 10.1 million workers, women represent $31 \%$ of the people employed in family farming (Table 3 ). transfer, among others) is fundamental. Additionally, access to public policies can also contribute to reducing the participation of children under 14 in agricultural production, which, according to the Agricultural Census, is close to $6.5 \%$ (Table 3). Table 4 shows the percentages of people employed in family farming in different Brazilian regions. The Northeast region of Brazil concentrates $46.6 \%$ of the people employed in family farming, as can be seen in Table 4. However, as mentioned by Ramos $(2014$, p. 33) we have in the Northeast "the largest contingent of low-income farmers, low schooling, in a situation of social vulnerability [...] family farming [...] suffers more, with the scarcity of natural resources (mainly water availability)"results from this, low productivity and consequently, lower income. Table 5 presents an overview of the education of rural producers linked to Brazilian family farming. With regard to schooling, the Agricultural Census indicates that women rural producers, often responsible for the administration of a production unit, have slightly higher education than men (Table 5). This result is relative, since the number of women rural producers is lower than the number of men. Women have better literacy skills at all levels (elementary and high school, regular and/or youth and adult education, as well as undergraduate and graduation education), as can be seen in Table 5. In fact, there is no way to talk about sustainable development without access to education and the reduction of inequalities. And women's access to education is essential to reduce income and gender inequalities.

Preservation of Woods and Forests: Examining the predominant Activities in family farming type agricultural establishments, we find that, in practically all, there is some type of animal, vegetable or forest production (Table 6).

Table 3. Employed people in agricultural establishments, by sex and age. Brazil, 2017

\begin{tabular}{lllll}
\hline & Men & Boysunder 14 years old & Women & Girls under 14 years old \\
\hline Non-family farming & 3.928 .224 & 81.947 & 1.061 .342 & 56.977 \\
Family farming & 6.797 .882 & 241.916 & 3.317 .677 & 199.212 \\
Total & 10.726 .106 & 323.863 & 4.379 .019 & 256.189 \\
\hline Source: IBGE (2017). Elaborated by the authors. & & &
\end{tabular}

Table 4. People employed in family farming, by region, in\%. Brazil, 2017

\begin{tabular}{cccccc}
\hline & North & Northeast & Midwest & Southeast & South \\
\hline Employed people & 15,4 & 46,6 & 5,5 & 16,5 & 16,0 \\
\hline Source: IBGE (2017). Elaborated by the authors.
\end{tabular}

Table 5. Education of the rural producer. Family farming. Brazil, 2017

\begin{tabular}{|c|c|c|c|}
\hline & Total & Men & Women \\
\hline Total & 3.897 .408 & 3.127 .736 & 769.672 \\
\hline Never went to school & 699.519 & 550.879 & 148.640 \\
\hline Literacy class - LC & 551.233 & 443.377 & 107.856 \\
\hline Literacy of youth and adults - LYA & 65.690 & 49.817 & 15.873 \\
\hline Elementary school & 991.660 & 826.347 & 165.313 \\
\hline Middle school & 227.382 & 187.745 & 39.637 \\
\hline High school & 753.990 & 599.198 & 154.792 \\
\hline LYA - youth and adult education and supplementary of elementary andmiddle school & 15.654 & 11.508 & 4.146 \\
\hline Old scientific, classic, etc. & 16.825 & 13.519 & 3.306 \\
\hline Regular high school & 412.688 & 319.629 & 93.059 \\
\hline High school or high school technician & 44.739 & 37.288 & 7.451 \\
\hline LYA - Youth and adult education and secondary school or high school education & 8.923 & 6.607 & 2.316 \\
\hline Undergraduation & 105.530 & 79.020 & 26.510 \\
\hline Graduation & 3.575 & 2.802 & 773 \\
\hline
\end{tabular}

Source: IBGE (2017). Elaborated by the authors.

It is evident that women are fundamental to the stability of family farming. On the one hand, because family farming cannot abstain of its workforce and, on the other, for the conservation of the nucleus and the family patrimony. This is because, women take care of the house and, generally, they are responsible for the care of small animals, the cultivation of vegetables and the production of sweets, cheeses, and pastries (breads and cookies), both for domestic consumption and for commercialization. Thus, the participation of women in family farming can be a means of reducing gender inequalities and violence against women (Ramos, 2014). Therefore, access to public policies (health, education, social security, income
The data show that, in fact, the interest of rural producers linked to family farming is agricultural production. These producers depend on the land for their subsistence, unlike traditional agriculture, where the land is a capital and, often, is at the service of real estate speculation. We also found that in $49 \%$ of establishments and $30 \%$ of the family farming area, vegetable production prevails. In other establishments, animal production, forestry or fishing and aquaculture predominate. It is worth mentioning the more than 151 thousand agricultural establishments dedicated, predominantly, to forest production, which is important for the sustainability (preservation) of the planet. 
Competitive Strategies for Family Agriculture: With the purpose of pointing out areas with the potential to add value to agricultural production, favoring economic and social development and, still, preserving the environment, we highlight agribusiness production and organic agriculture (Table 7). an enormous growth potential. Castro Neto et al. (2010) studied the relationships between family farming, organic production, and sustainable development. The authors found that organic agriculture represents a possibility for small producers to diversify and add value to production.

Table 6. Number of establishments and area with agricultural production. Family farming. Brazil, 2017

\begin{tabular}{|l|l|l|}
\hline & Total & Área (ha) \\
\hline Agricultural establishments & 3.897 .408 & 80.891 .084 \\
\hline Production of temporary crops & 1.321 .907 & 18.015 .956 \\
\hline Horticulture and floriculture & 126.887 & 864.987 \\
\hline Production of permanent crops & 439.663 & 5.729 .248 \\
\hline Production of certified seeds and seedlings & 2.517 & 41.821 \\
\hline Livestock and breeding of other animals & 1.842 .895 & 52.676 .537 \\
\hline Forest production - planted forests & 37.759 & 835.605 \\
\hline Forest production - native forests & 113.283 & 2.591 .045 \\
\hline Fishing & 7.654 & 60.913 \\
\hline Aquaculture & 4.843 & 74.972 \\
\hline
\end{tabular}

Table 7. Number of establishments, quantity produced and sold and value of agribusiness production in agricultural establishments. Family farming. Brazil, 2017

\begin{tabular}{|c|c|c|c|c|}
\hline & Number of establishments & Quantity produced & Quantity sold & Production Value (R\$ thousand) \\
\hline Cachaça (sugarcane liquor) & 8.664 & 33342 thousand liters & 26339 thousand liters & 148.016 \\
\hline Cotton & 121 & 449 tonnes & 448 tonnes & 2.169 \\
\hline Cottonseed & 19 & 20 tonnes & 17 tonnes & 20 \\
\hline Rice & 30.544 & 23447 tonnes & 7811 tonnes & 47.107 \\
\hline Roasted coffee beans & 1.131 & 2689 tonnes & 1607 tonnes & 18.307 \\
\hline Ground roasted coffee & 8.360 & 1788 tonnes & 1034 tonnes & 21.262 \\
\hline Cajuína (cashew beverage) & 595 & 765 thousand liters & 580 thousand liters & 3.585 \\
\hline Milk cream & 2.084 & 308 tonnes & 151 tonnes & 2.729 \\
\hline Sweets and jams & 55.701 & 9036 tonnes & 7193 tonnes & 84.316 \\
\hline Cassava flour & 315.611 & 591132 tonnes & 425406 tonnes & 1.612 .265 \\
\hline Corn meal & 4.083 & 7453 tonnes & 2568 tonnes & 15.915 \\
\hline Tobacco rope & 6.512 & 5748 tonnes & 2532 tonnes & 36.600 \\
\hline Vegetables (processed) & 8.153 & 5597 tonnes & 4503 tonnes & 17.087 \\
\hline Liquors & 1.347 & 1856 thousand liters & 144 thousand liters & 6.851 \\
\hline Butter & 9.951 & 709 tonnes & 424 tonnes & 9.041 \\
\hline Molasses & 18.803 & 8276 thousand liters & 5521 thousand liters & 36.295 \\
\hline Vegetable oils & 15.825 & 2723 thousand liters & 1695 thousand liters & 18.482 \\
\hline Breads, cakes and cookies & 62.970 & 20980 tonnes & 7464 tonnes & 180.615 \\
\hline Fruit pulp & 20.812 & 18048 tonnes & 15269 tonnes & 112.540 \\
\hline Cheese and cream cheese & 143.921 & 149711 tonnes & 134459 tonnes & 1.828 .516 \\
\hline Rapadura (sugarcane sweet) & 15.838 & 16668 tonnes & 13387 tonnes & \begin{tabular}{|l|l|}
74.562 \\
\end{tabular} \\
\hline Fruit juice & 44.296 & 12472 thousand liters & 4220 thousand liters & 73.638 \\
\hline Grape wine & 7.056 & 14305 thousand liters & 7043 thousand liters & 73.743 \\
\hline Beef meat (green) & 103.633 & 36317 tonnes & 8266 tonnes & 388.692 \\
\hline Pork meat (green) & 126.914 & 27954 tonnes & 4651 tonnes & 254.652 \\
\hline Meat from other animals (green) & 101.313 & 15156 tonnes & 5404 tonnes & 177.286 \\
\hline Treated meat (dried, salt-cured) & 2.456 & 275 tonnes & 171tonnes & 3.999 \\
\hline Sausages & 39.980 & 4958 tonnes & 2374 tonnes & 74.503 \\
\hline Leathers & 8.646 & 1067 tonnes & 1029 tonnes & 1.677 \\
\hline Charcoal & 48.570 & 538757 tonnes & 485332 tonnes & 328.985 \\
\hline Wood products & 2.091 & 1693 thousandm $^{3}$ & 1238 thousand $\mathrm{m}^{3}$ & 28.739 \\
\hline Other products & 32.443 & 89786 tonnes & 44197 tonnes & 572.398 \\
\hline \multirow[t]{2}{*}{ Tapioca } & 63.387 & 25400 tonnes & 17001 tonnes & 97.076 \\
\hline & 1.311 .830 & & & 6.351 .668 \\
\hline
\end{tabular}

Source: IBGE (2017). Elaborated by the authors.

Regarding agribusiness production (Table 7), only $34 \%$ of the establishments offer goods of this nature. Agribusiness production is diversified. However, we see an important opportunity for the growth of family farming in this area of production. Agribusiness production has the capacity to add value to products from family farming, as well as it favors commercialization, as it allows reaching consumers in all parts of the world. In addition, it contributes to raising income and improving the quality of life of rural producers and their families. Therefore, it is evident, once again, that family farming can contribute to the sustainable development of the country. According to IBGE (2017), agribusiness production yielded approximately $\mathrm{R} \$ 6.35$ billion for family agriculture in 2017, with an emphasis on the production of cassava flour, cheese and cream cheese, meat (beef, pork, and other animals). Considering that the value of family farming production was equivalent to $\mathrm{R} \$ 107$ billion in 2017, there is,
Organic agriculture must be strengthened, not only because it is important for the preservation of the environment, but also because it is a source of healthy food. However, the low adhesion of rural producers to organic production points to the insufficiency of public policies, such as, the price policy of CONAB. Table 8 shows the distribution, in Brazil, of family farms with vegetable, animal and vegetable and animal organic production. The strengthening of family farming also requires, sources of financing, adequate technical guidance (production and management), as well as the establishment of partnerships with the public authorities (for example, channels for distribution and certification). The limited organic production and the reduced industrialization of production by family producers reveals the great potential to increase the income of family farming, with environmental preservation and generation of jobs and income. 
Table 8. Distribution of family farming establishments with vegetable, animal and vegetable and animal organic production. Brazil, 2017

\begin{tabular}{|l|l|l|l|l|l|}
\hline Regions & $\begin{array}{l}\text { Family farming } \\
\text { establishments }\end{array}$ & $\begin{array}{l}\text { Organic } \\
\text { production }\end{array}$ & $\begin{array}{l}\text { Vegetable organic } \\
\text { production }\end{array}$ & $\begin{array}{l}\text { Organic animal } \\
\text { production }\end{array}$ & $\begin{array}{l}\text { Organic vegetable and } \\
\text { animal production }\end{array}$ \\
\hline Brazil & 3.897 .408 & 49.330 & 28.490 & 12.626 & 8.214 \\
\hline North & 480.575 & 6.625 & 4.196 & 1.339 & 1.090 \\
\hline Northeast & 1.838 .846 & 13.385 & 7.328 & 2.565 & 3.492 \\
\hline Southeast & 688.945 & 14.169 & 7.871 & 4.483 & 1.815 \\
\hline South & 665.767 & 10.230 & 6.630 & 2.283 & 1.317 \\
\hline Midwest & 223.275 & 4.921 & 2.465 & 1.956 & 500 \\
\hline
\end{tabular}

Source: IBGE (2017). Elaborated by the authors.

Table 9. Number of establishments that obtained financing and the type of financial agent. Family farming. Brazil, 2017

\begin{tabular}{|l|l|l|l|}
\hline & Total establishments & No credit programs & Credit programs \\
\hline Total & 601.191 & 279.157 & 322.034 \\
\hline Banks & 497.486 & 239.559 & 257.927 \\
\hline Credit unions & 79.652 & 31.048 & 48.604 \\
\hline Governments & 43.471 & 6.879 & 36.592 \\
\hline Raw material traders & 613 & 489 & 124 \\
\hline Suppliers (inputs and/or equipment) & 1.926 & 1.456 & 470 \\
\hline Integrating company & 5.951 & 4.576 & 1.375 \\
\hline Other financial institutions (except banks and cooperatives) & 3.260 & 2.522 & 738 \\
\hline Non-Governmental Organization - NGO & 239 & 120 & 119 \\
\hline Relatives or friends & 1.586 & 1.434 & 152 \\
\hline Other agentes & 2.014 & 1.230 \\
\hline
\end{tabular}

Source: IBGE (2017). Elaborated by the authors.

Consequently, family farming presents itself as a viable opportunity for sustainable development, both locally and in the country. With regard to the financing of family farming, the National Family Farming Strengthening Program (PRONAF) is its main instrument and provides resources for funding and investing in the production, processing, industrialization, and services of agricultural production (Bianchini, 2015). Table 9 presents the number of establishments that obtained financing and the type of financial agent throughout the country, in the year 2017. As can be seen in Table 9, just over 320 thousand family farmers have benefited from PRONAF financing. Anyway, there seem to be many difficulties in obtaining credit. Table 9 also presents that only $15 \%$ of family farming establishments obtained some type of financing, with a large number of establishments that were successful in raising funds having to resort to other sources of credit other than the government credit programs. Certainly, such a shortage of credit limits the potential of family farming as a tool that promotes sustainable development in the country. Among other things, because thousands of producers resort to unofficial credit, with high interest rates, tight deadlines and see themselves obliged to offer guarantees that threaten the very survival of the business. Millions of other family farmers, on the other hand, do not have access to any form of credit.

Family Agriculture and the possibilities of sustainable local development: The traditional models of development were based on the idea of industrialization at any cost. However, this development strategy resulted, in most cases, in social and environmental degradation. Sustainable development is about economic growth and also social inclusion, popular participation, equality, solidarity, as opposed to concentration, competition, exclusion, poverty, and inequality. Development is intrinsically linked to people, who must be the main beneficiaries of economic growth. People who feel part of a group and share a lifestyle. Sustainable local development presupposes that instead of the locality receiving pre-established actions and policies, we value already existing social organizations, organized civil society, as well as we take advantage of the available human and social resources, and find ways for development (Ramos, 2013). Finally, development presupposes the involvement of people and respect for the local cultural identity. In this sense, family farming is an important instrument for sustainable local development. As demonstrated, family farming generated 10.1 million jobs and income equivalent to $\mathrm{R} \$ 107$ billion in 2017. It contributes to the reduction of gender inequalities, with 3.3 million women employed in family farming.
Family farming is also important for the country's poorest regions. In this sense, the Northeast concentrates $46 \%$ of the people employed in family farming. Family farming also preserves 13.3 million hectares in woods and forests. In addition, agribusiness production can contribute to local development, as it makes it possible to add value to rural production and contemplates the generation of higher quality jobs, both in production and in management (managers, administrators, secretaries, accountants, etc.). As shown, agribusiness production represents only $6 \%$ of the value of family agriculture production. Therefore, there is a great potential for growth. Another possibility of exploit the potential of family farming for local sustainable development is organic farming. This type of production is suitable for small properties, it is intensive in knowledge and innovation, a requirement for sustainable development. Organic farming is environmentally, socially, and economically sustainable. And coordination between producers and the public authorities can enable the expansion of organic production and contribute to local development. It is worth mentioning the institutional support for organic agriculture through CONAB, which offers privileged treatment to organic producers, mainly through the price policy.

\section{CONCLUSION}

Society must have a central role in the local development process. As development presupposes social and economic inclusion, equality of income and gender, conservation of natural resources and preservation of the environment. These requirements qualify the development, which can then be called sustainable. Family farming is a path that leads to sustainable development, with social, economic inclusion and respect for the environment. Family farming contributes to the generation of jobs and income and improves the quality of life for millions of rural workers. Strengthens and mobilizes rural communities. It reduces the rural exodus. Consequently, it plays an important role in the sustainable development of Brazilian municipalities, especially small and medium-sized municipalities. Another important aspect for local development, concerns the adaptation of productive activities to the territory. The family farmer is adapted to the region. Knows and respects local values, beliefs, and stories. Thus, the adequacy of production to the local way of life. It should be noted that without respect for the local cultural identity, it will be difficult to implement a sustainable development model. Family farming is relevant to the Brazilian society, as it contributes to the preservation of the environment, including preserving woords and 
forests. By organizing production differently from traditional agriculture, family farming helps to conserve natural resources. Family, artisanal and agribusiness agricultural production can contribute to sustainable local development, at a time when not all localities have attractions that awaken interest of large enterprises, especially industrial ones. Among the various possibilities for strengthening family farming within the reach of Brazilian municipalities, we have to facilitate the commercialization of production. For this, the organization of distribution centers and open fairs is important. In addition, it is possible to strengthen family farming through training and financing of agribusiness production. In any case, the success of any sustainable local development strategy requires the establishment of strategies developed jointly with the various social actors. It should be noted that in family farming, the presence of women is decisive. In addition to work, women play a central role in raising children, for stability and family unity, in the bond with the land, among other things. As an answer to the research question, it can be said that family farming represents a viable opportunity for sustainable local development. For that, the local government needs to recognize that the sector is a source of development and that, through partnerships, it can contribute to transforming the local economic, social, environmental, and cultural reality. Finally, it is emphasized that the results achieved in this study do not exhaust the topic, and further studies are necessary in order to consolidate this important theme. The research was restricted to collecting data in public documents, especially data extracted from the Agricultural Census (IBGE, 2017). However, it is suggested that more studies be carried out, including visiting properties and listening to family farmers.

\section{REFERENCES}

ALBAGLI, S. (2006). Conhecimento, inclusão social e desenvolvimento local. Inclusão Social, Brasília, v. 1, n. 2, p. 1722, Apr./Sep.

ARIENTI, W. L. (2008). Uma análise regulacionista das reformas do Estado capitalista: Rumo ao Estado pós-fordista? Textos de Economia, Florianópolis, v. 8, n. 1, p. 1-36.

BATALHA, M. O.; BUAINAIN, A. M.; SOUZA FILHO, H. M. (2005). Tecnologia de gestão e agricultura familiar. In: SOUZA FILHO, H. M.; BATALHA, M. O. (Orgs.). Gestão Integrada da Agricultura Familiar. São Carlos: EDUFSCAR, p. 43-66.

BIANCHINI, V. (2015). Vinte anos do PRONAF - 1995-2015: avanços e desafios. Brasília: MDA.

BRASIL (2006). LEI $\mathrm{N}^{\circ}$ 11.326, DE 24 DE JULHO DE 2006.Estabelece as diretrizes para a formulação da Política Nacional da Agricultura Familiar e Empreendimentos Familiares Rurais. Available in: http://www.planalto.gov.br/ ccivil_03/_Ato2004-2006/2006/Lei/L11326.htmAccessed in: 2020 Aug., 26.

(2017). DECRETO No 9.064/17, 31 DE MAIO DE 2017. Dispõe sobre a Unidade Familiar de Produção Agrária, institui o Cadastro Nacional da Agricultura Familiar e regulamenta a Lei $\mathrm{n}^{\mathrm{o}} 11.326$, de 24 de julho de 2006. Available in: https:/www2.camara.leg.br/legin/fed/decret/2017/decreto-906431-maio-2017-785001-publicacaooriginal-152929pe.htmlAccessed in: 2021 Jan., 10.

BRUNO, R. (2016). Desigualdade, agronegócio, agricultura familiar no Brasil. Estudos Sociedade e Agricultura, Rio de Janeiro, v. 24, n. 1, p. 142-160, Apr.

BUAINAIN, A. M. (2006). Agricultura familiar, agroecológica e desenvolvimento sustentável: questões para debate. Brasília: IICA.

CASTRO NETO, N; DENUZI, V. S.; RINALDI, R. N.; STADUTO, J. A. R. (2010). Produção orgânica: uma potencialidade estratégica para a agricultura familiar. Revista Percurso, Maringá, v. 2, n. 2, p. 73-95.

CHIZZOTTI, A. (2018). Pesquisa em ciências humanas e sociais. 9. ed. São Paulo: Cortez.
CMMAD (1998). COMISSÃO MUNDIAL SOBRE MEIO AMBIENTE E DESENVOLVIMENTO. Nosso futuro comum. Rio de Janeiro: Fundação Getúlio Vargas.

CONAB (nd) COMPANHIA BRASILEIRA DE ABASTECIMENTO. Agricultura familiar. Available in: https://www.conab.gov.br/perguntas-frequentesAccessed in: 2020 Aug., 26.

DESLAURIERS, J.-P.; KÉRISIT, M. (2010). O delineamento de pesquisa qualitativa. In: POUPART, J. et al. (Orgs.). A pesquisa qualitativa: enfoques epistemológicos e metodológicos. 2.ed. Petrópolis: Vozes, p.127-53.

DINIZ, E. M. (2011). Os resultados da Rio +10. Revista do Departamento de Geografia, São Paulo, v. 15, p. 31-35.

DOCAMPO, M. G. (2007) El desarrollo local en el marco de los procesos de globalización. In: DOCAMPO, M. G. (Ed.). Perspectivas teóricas en desarrollo local. 1. ed. La Coruña: Netbiblo, p. 01-33.

FAO (2017) ORGANIZAÇÃO PARA A ALIMENTAÇÃO E AGRICULTURA. Plataforma de conocimientos sobre agricultura familiar. Available in: http://www.fao.org/familyfarming/es/ Accessed in: 2020 Aug., 30.

GEORGESCU-ROEGEN, N. (2012).O decrescimento: Entropia, ecologia e economia. São Paulo, SP: Editora Senac.

GIL, A. C. (2019) Métodos e técnicas de pesquisa social. 7. ed. São Paulo, Atlas.

GUIMARÃES, R; FONTOURA, Y. (2012). Desenvolvimento sustentável na Rio+20: discursos, avanços, retrocessos e novas perspectivas. Cadernos EBAPE.BR, Rio de Janeiro, v. 10, n. 3, p. 508-532, Sep.

IBGE (nd) INSTITUTO BRASILEIRO DE GEOGRAFIA E ESTATÍSTICA. Censo agropecuário2017(nd).Available in: https://www.ibge.gov.br/estatisticas/economicas/agricultura-epecuaria/21814-2017-censoagropecuario.html?=\&t=destaquesAccessed in: 2020 Aug., 31 .

IPEA (2018). INSTITUTO DE PESQUISA ECONÔMICA APLICADA. Agenda 2030. ODS - Metas Nacionais dos Objetivos de Desenvolvimento Sustentável. Brasília, IPEA.

KANG, T. H. (2011) Justiça e desenvolvimento no pensamento de Amartya Sen. Revista de Economia Política, São Paulo, v. 31, n. 3, p. 352-369, Sep.

KOHLRAUSCH, L. (2019). Sentidos do desenvolvimento local: uma análise dos projetos políticos manifestos no plano plurianual de cinco capitais (2017-2020). 2019. 160 f. Dissertação (Dissertação em Políticas Públicas) - Universidade Federal do Rio Grande do Sul, Porto Alegre.

KRONENBERGER, D. (2011). Desenvolvimento local sustentável: uma abordagem prática. São Paulo: SENAC.

MARTINS, S. R. O. (2002). Desenvolvimento Local: questões conceituais e metodológicas. Interações - Revista Brasileira de Desenvolvimento Local, Campo Grande, v. 3, n. 5, p. 51-59, Sep.

MEADOWS, D. H. et al (1972). The limits to growth. New York: Universe Books.

NAÇÕES UNIDAS (nd) A ONU e o meio ambiente. Available in: https://nacoesunidas.org/acao/meio-ambiente/. Accessed in: $2020 \mathrm{Jul}, 07$.

NAVARRO, Z. (2016). O Mundo rural no novo século (um ensaio de interpretação). In. VIEIRA FILHO, J. E.; GASQUES, J. G. (Orgs.). Agricultura, transformação produtiva e sustentabilidade. Brasília: Ipea, p. 25-63.

PNUD (nd). PROGRAMA DAS NAÇÕES UNIDAS PARA O DESENVOLVIMENTO. Atlas do Desenvolvimento Humano no Brasil. Available in:http://www.atlasbrasil.org.br/. Accessed in: 2020 Jul., 05.

RAMOS, C. P. (2014). Mulheres rurais atuando no fortalecimento da agricultura familiar local. Revista Gênero, Rio de Janeiro, v. 15, n. 1, p. 29-46.

RAMOS, S. E. V. (2013) Sustentabilidade e desenvolvimento local. Curitiba: Instituto Federal do Paraná.

RICHARDSON, R. J. (2017). Pesquisa Social: Métodos e Técnicas. 4. ed. São Paulo: Atlas. 
RIEDNER, L, N. et al. (2018). Avaliação da dimensão ambiental da sustentabilidade da agricultura familiar no Oeste do estado do Paraná, Revista Metropolitana de Sustentabilidade, v. 8, n. 1, p. 52-71.

ROMEIRO, A. R. (2012) Desenvolvimento sustentável: uma perspectiva econômico-ecológica. Estudos Avançados, São Paulo, v.26, n.74, p.65-92.

SACHS, I. (2008). Caminhos para o Desenvolvimento Sustentável. Rio de Janeiro: Garamond.

SACHS, I. (2010). Barricadas de ontem, campos de futuro. Estudos Avançados, São Paulo, v. 24, n. 68, p. 25-38.

SANTOS, C. F. et al. (2014) A agroecologia como perspectiva de sustentabilidade na agricultura familiar. Ambiente \& Sociedade, São Paulo, v. 17, n. 2, p. 33-52, Apr./Jun.

SCHNEIDER, S. (2003). Teoria social, agricultura familiar e pluriatividade. Revista Brasileira de Ciências Sociais, São Paulo, v. 18, n. 51 p. $99-122$.

SEN, A (2010). Desenvolvimento como Liberdade. São Paulo: Companhia das Letras.

SEVERINO, A. J.(2016). Metodologia do trabalho científico. 24. ed. rev. atual. São Paulo: Cortez.

SOLOW, R. (1974). The economics of resources or the resources of economics. The American Economic Review, v. 64, n.2, p. 1-14.

TRIVINOS, A. N. S. (2015) Introdução à pesquisa de ciências sociais. 1. ed., 18 reimp. São Paulo: Atlas.
UNITED NATIONS (2002). Plan of Implementation of the World Summit on Sustainable Development. Johannesburg: United Nations. Available in: https://www.un.org/esa/sustdev/ documents/WSSD_POI_PD/English/WSSD_PlanImpl.pdf. Accessed in: $2020 \bar{J}$ Jul., $\overline{1} 6$.

UNITED NATIONS (2015). The Millennium Development Goals Report 2015. Available in: https://www.un.org/millenniumgoals/ 2015_MDG_Report/pdf/MDG\%202015\%20rev\%20(July\%201). pdf. Accessed in: 16 de jul. 2020.

VAN BELLEN, H. M.; PETRASSI, A. C. M. A. (2016). Dos limites do crescimento à gestão da sustentabilidade no processo de desenvolvimento. Revista NECAT - Revista do Núcleo de Estudos de Economia Catarinense, Florianópolis, v. 5, n. 10, p. 8-30.

VEIGA, J. E. (2015). Para entender o desenvolvimento sustentável.São Paulo: Editora 34, 2015.

VERGARA, S. C. (2013). Projetos e relatórios de pesquisa em administração. 14 ed. São Paulo: Atlas.

WCED (1987). WORLD COMMISSION ON ENVIRONMENT AND DEVELOPMENT. Our Common Future. Oxford: Oxford University Press.

YIN, R. K.(2015) Estudo de caso: planejamento e métodos. 5. Ed. Porto Alegre: Bookman, 2015. 